\title{
Preparation of Lead, Lead Alloy(S) and Other Salts from Exhausted Rechargeable Lead Batteries
}

\author{
Mahmoud Abdel-Hamed Rabah ${ }^{1, *}$, Maie Ibrahim Abdul Aziz El-Gammal², Mahmoud Salem Ibrahim², Omar Mohamed Helmy Abdul \\ $\mathrm{Aziz}^{2}$
}

${ }^{1}$ Chemical and electrochemical metallurgy, Central metallurgical research and development Institute CMRDI, Helwan,11421, Cairo, Egypt.

${ }^{2}$ Environmental Science Department, Faculty of Science, Damietta Univ. Egypt

\begin{tabular}{l} 
A R T I C L E I N F O \\
\hline Article history: \\
Received: 04 March, 2019 \\
Accepted: 16 August, 2019 \\
Online: 25 August, 2019 \\
\hline Keywords: \\
Rechargeable batteries \\
Pure lead \\
Secondary lead-aluminium \\
Magnesium alloy \\
Nickel and cobalt \\
Hydrometallurgy
\end{tabular}

\section{Introduction}

Rechargeable batteries are usually used for temporary power supply in general and in houses in particular in case the main power shutoff accidentally The Bureau of Mines [1] has investigated an electrolytic recycling process to recover lead and improve secondary recovery of metals and minerals from scrap batteries Metallic fraction of the crushed batteries is directly melted and cast as anodes for electro refining The sludge is leached with ammonium carbonate [(NH4)2CO3] and ammonium bisulfite (NH4HSO3) to convert lead sulfate (PbSO4) and lead dioxide $(\mathrm{PbO} 2)$ to lead carbonate $(\mathrm{PbCO} 3), \ldots$ The lead metal grids and plates are separated from the sludge by ball milling, washing, and

*Mahmoud Abdel-Hamed Rabah, Email: mrabah010@gmail.com screening by the Betts process using waste fluosilicic acid as the electrolyte.

Battery is made of groups of plates connected together by external flag terminal made of lead alloy. Lead oxide(s), sulphate powders filling in the grids openings to form the electrically active material. In the charged state, the negative plate paste is leadcalcium grid loaded with lead sulphate; the positive electrode is lead dioxide. Both of these lead materials are in a spongy form to optimize surface area and thereby maximize the electrical capacity [1] The conductivity media is potassium hydroxide in low quantity just sufficient to moisten the electrode paste. In the discharging state, the negative lead plate loses electrons and got oxidized to a higher lead oxidation state. Lead-calcium alloy provides benefits of good grid density, conductivity, \& tensile 


\section{M.A. Rabah et al. / Advances in Science, Technology and Engineering Systems Journal Vol. 4, No. 4, 529-538 (2019)}

strength. It reduces water consumption over life of battery, it also reduces electrolyte \& hydrogen gas evolution. Better selfdischarge characteristics- (typically $.05 \%$ per day at $25^{\circ} \mathrm{C}$ ) is attained with this alloy together with stable rate under float charge over the life of the battery and constant current draw [2] Chen et al [3] repor4ted recovery of lead from fly ash of waste lead-acid batteries. The lead salt is lead sulphate (PbSO4) and lead oxy sulphate ( $\mathrm{Pb} 2 \mathrm{OSO} 4)$. Nitric acid and sodium hydroxide were used for leaching of the fly ash sample. With $\mathrm{S} / \mathrm{L}$ of $60 \mathrm{gL}-1$, the leach extent of $\mathrm{Pb}$ was $43 \%$ and $67 \%$ in $2 \mathrm{M}$ acidic and basic solutions, respectively. Anglesite is soluble in $\mathrm{NaOH}$ whereas lanarkite is mildly soluble in HNO3. Lead metal was recovered by electrolysis from the leach solution with the help of an electrolytic cell fitted with graphite coated with titanium (Ti-DSA) anodes and stainlesssteel cathode. Properties of anodes deposited with lead dioxides were analyzed by cyclic voltammetry... Junqing et al, 2012, [4] recovered method, in which high purity metallic $\mathrm{Pb}$ is directly produced by electrolyzing $\mathrm{PbO}$ obtained from waste lead acid batteries in alkaline solution A hydrometallurgical process has been proposed $[5,6]$ to recover valuable metals from spent lithiumion batteries in citric acid media. A process was reported including the steps of calcinations of a spent paste treated with an alkali carbonate or hydroxide or any mixture thereof, and elemental sulphur at a temperature of up to $600^{\circ} \mathrm{C}$., followed by washing with water. The heat treated and washed paste was dissolved in an alkali molten electrolyte, and lead was electro-won from the alkali molten electrolyte. The spent electrolyte was reused in the process [7]. Molten flux salts displayed good thermal stability and solvent properties; these characteristics helped their use in materials preparation [8], solar power plants [9], and the getting rid of paints or coating from metal surfaces [10]. An up to date technology, adapted a molten salt to the smelting processes of antimony and bismuth through the use of sodium hydroxide and a mixed molten salt in the $\mathrm{NaOH}-\mathrm{Na} 2 \mathrm{CO} 32 \mathrm{CaO}$ system $[11,12]$. Separation of minor elements using Lewisite exchange resin was reported by Badawy et al. [13]. Yoheeswaran1 et al [14], recovered lead metal from used lead acid batteries, by the hydrometallurgical method. The treatment of used batteries for recovering lead was claimed to be important from the point of view of lead production as well as pollution abatement as otherwise the battery scarp leads to serious disposal problems. The pyrometallurgical and other methods suggested in the past decades, were found to be impracticable, and a new method was investigated. Lead metal recovery from spent lead acid batteries applying an electrochemical method comprising two successive steps; lead leaching and electrode position. It was found that $95 \%$ of lead metal was leached by $2 \mathrm{M}$ of nitric acid and the electrode position step more than $90 \%$ of lead metal could be recovered with low current efficiency from the leaching solution. The method adopted was reported to be promising and had great potential for removal of lead from used lead acid batteries. E-waste generation was growing at about $15 \%$ and is expected to cross 800,000 tons per year in 2012 in some countries like India. The composition of spent batteries was very diverse and contained over 1000 different substances, which falls under organic and inorganic fractions [Viraja Bhat, 15]. Yunjian Ma and Kiqyiang Qui [16] investigated a compatible environmental process consisted of hydrometallurgical desulfurization and vacuum thermal reduction to recycle lead. Lead paste was desulfurized with sodium carbonate, by which, the content of sulfur declined from $7.87 \%$ to $0.26 \%$. Charcoal was used to reduce the desulphurization lead paste under vacuum. Under the optimized reaction conditions, i.e., vacuum thermal reduction at temperature $850{ }^{\circ} \mathrm{C}$ under $20 \mathrm{~Pa}$ for $45 \mathrm{~min}$,

The aim of this work is to extract metal lead. Lead aluminiummagnesium alloy and some salts from exhausted plates and grids of electrolyte-free rechargeable lead batteries... Recovery of lead metal was performed using hydrometallurgical and pyro metallurgy whereas the alloying elements of aluminium and Magnesium were extracted by solvent extraction technique, Parameters influencing these processes such as temperature, time, and $\mathrm{pH}$ value and mole ratio of the reagents were studied.

\section{Materials and Methods}

\subsection{Experimental Details}

A sample of about ten $\mathrm{Kg}$ of used rechargeable lead batteries was supplied by the waste collection stores, Cairo. The sample was washed with water and left to dry in normal ambient conditions. Figure 1 shows a photograph of the collected spent rechargeable acid lead batteries

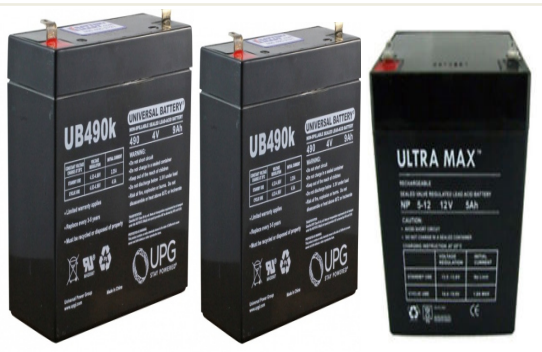

Figure 1 Different models of the spent batteries used in this study

The chemicals used for leaching, precipitation, separation and salts preparation were chemically pure grade. Nitric, formic, acetic acids and calcium carbonate, oxide and hydroxide. Sodium, and potassium were of ADWIC supplier (Egypt) Table 1 summarizes the properties of chemicals used.

Table 1 Properties of the chemicals used in this study

\begin{tabular}{|c|c|c|c|}
\hline Supplier & Purpose & Properties & Product \\
\hline $\begin{array}{c}\mathrm{CH}_{3} \mathrm{COOH} \\
\text { Nitric acid } \\
\mathrm{H}_{2} \mathrm{SO}_{4} \\
\mathrm{HCl}\end{array}$ & $\begin{array}{l}\text { 90\% } \\
\text { SP. Gr. } 1.044- \\
\text { 1.049 } \\
\text { sP.Gr.1.18 (AR) } \\
\text { Min. assay } 36 \% \\
\text { fuming } 69 \% \\
\mathrm{H}_{2} \mathrm{SO}_{4} \quad 95-97 \% \\
\text { Extra pure } \\
\text { SP.Gr.1.18 (AR) }\end{array}$ & $\begin{array}{l}\text { Leaching } \\
\text { Process }\end{array}$ & $\begin{array}{l}\text { Riedel- de } \\
\text { Hein } \\
\text { ADWIC } \\
\text { Riedel- de } \\
\text { Hein } \\
\text { ADWIC }\end{array}$ \\
\hline $\begin{array}{c}\mathrm{Ca} \\
\text { carbonate, } \\
\text { EJSF2 } \\
\text { Ca oxide }\end{array}$ & $\begin{array}{c}99.3,1.6 \mathrm{um} \\
3.34 \mathrm{~g} / \mathrm{cm}^{3}, 1.57 \\
\text { um }\end{array}$ & $\begin{array}{c}\text { Synthesis } \\
\text { process }\end{array}$ & $\begin{array}{c}\text { Green } \\
\text { Egypt } \\
\text { Sigma } \\
\text { Aldrich }\end{array}$ \\
\hline
\end{tabular}




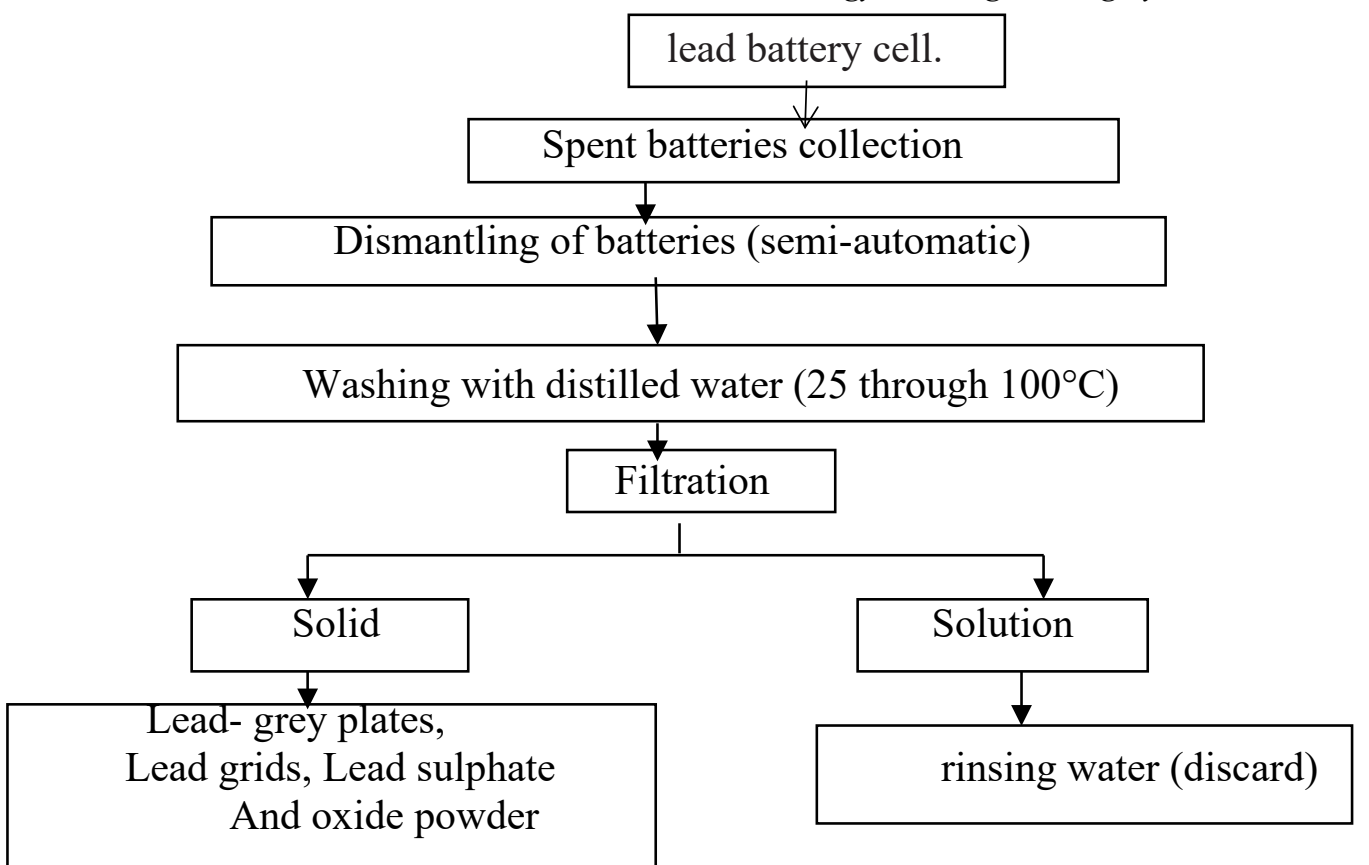

Fig. 2 A conceptual process flow sheet to method to recover lead and lead alloys from exhausted rechargeable acid.

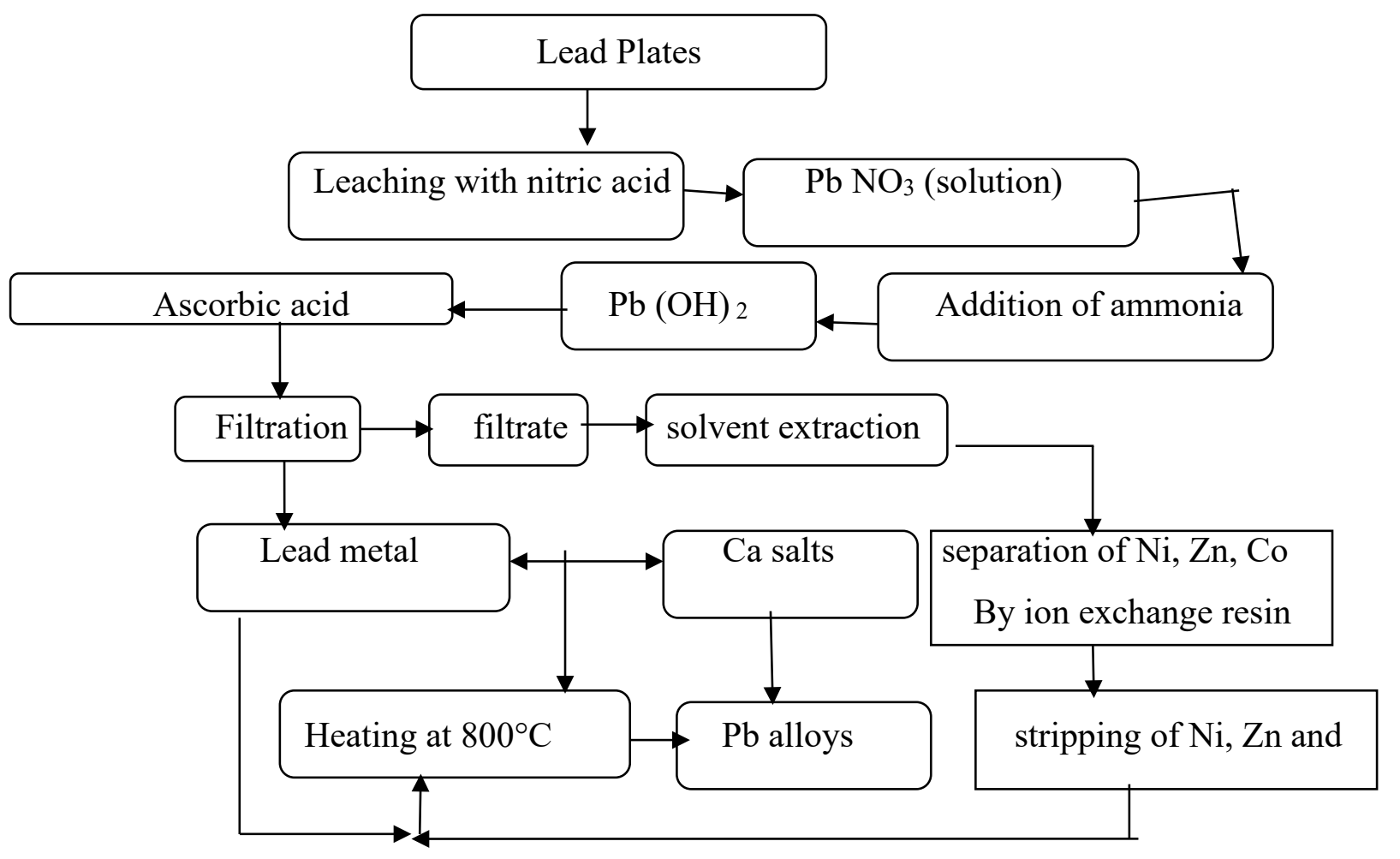

Fig. 3 Process flow sheet for the preparation of lead alloys from spent grids of the battery

Organic solvents were used to extract soluble ions of some metals that go into the filtered solution after the leaching process. Table 2 shows the type and properties of the solvents used.

An ion exchange resin Lewatite MP 600 (Merck) was used for ion exchange experiments. It was converted to chloride form before use by thoroughly washing with $0.1-2 \mathrm{M} \mathrm{HCl}$ acid in a column for 3 days. It was then washed with aqueous ethanol $(70 \%)$. The treated resin was then dried under vacuum at $25^{\circ} \mathrm{C}$. 
Table 2 Properties of the solvents used in this work

\begin{tabular}{|c|c|c|c|}
\hline Solvent \# & Property & Solvent \# & Property \\
\hline $\begin{array}{c}\text { (1) Acetic } \\
\text { acid }\end{array}$ & $(0.1 \mathrm{M}-1 \mathrm{M})$ & $\begin{array}{c}\text { (3) Acetone } \\
/ \text { water }\end{array}$ & $25 \%-75 \%$ \\
\hline $\begin{array}{c}\text { (2) Ethanol/ } \\
\text { water }\end{array}$ & $10 \%-75 \%$ & $\begin{array}{c}\text { (4) Diethyl } \\
\text { ether }\end{array}$ & $50 \%$ \\
\hline
\end{tabular}

\subsection{Method of leaching and preparation of lead-calcium alloy from $S L B$.}

Figures 2 and 3 show a process flow sheet of the applied method to recover lead and lead-alloys from exhausted rechargeable acid.

An ion exchange resin Lewatite MP 600 (Merck) was used for ion exchange experiments. It was converted to chloride form before use by thoroughly washing with $0.1-2 \mathrm{M} \mathrm{HCl}$ acid in a column for 3 days. It was then washed with aqueous ethanol $(70 \%)$. The treated resin was then dried under vacuum at $25^{\circ} \mathrm{C}$.

A dyestuff of 4-(2-pyridylazo) resorcinol (product of Merck) was used weighing $10 \mathrm{~g}$ of molecular weight amounting to 215.21 was used. A $0.02 \mathrm{M}$ stock solution was prepared by dissolving $0.538 \mathrm{~g}$ in 0.25 -liter $80 \%$ aqueous ethanol. Standard $0.2 \mathrm{M}$ bisodium hydrogen phosphate $\mathrm{Na}_{2} \mathrm{HPO}_{4}$ and $0.1 \mathrm{M}$ citric acid $\mathrm{C}_{6} \mathrm{H}_{8} \mathrm{O}_{7} \cdot \mathrm{H}_{2} \mathrm{O}$ solutions were used as buffer solutions for $\mathrm{pH}$ control.

\subsection{Method of leaching and preparation of lead-calcium alloy from $S L B$.}

Figures 2 and 3 show a process flow sheet of the applied method to recover lead and lead-alloys from exhausted rechargeable acid.

\subsection{Determination of lead and other metals in the battery.}

Lead. Calcium and other metals content in the exhausted grids were determined by XRF. Leaching was done by $3 \mathrm{M}$ nitric acid. The obtained leachate was analyzed by ICP. The unleached residue was also analyzed by XRD.

\subsection{Description of the method used to extract minor metals in the leached solution}

The method used was given by Badawy et al. [13]. The resin was de-mineralized by packing $1 \mathrm{~g}$ of the resin in a glass column through which $\mathrm{HCl}$ acid $(2 \mathrm{M}-0.01 \mathrm{M})$ was passed for nearly three days to assure that all the resin converts to the chloride form. It was leached with $1 \mathrm{~L}$ of $1 \%\left(\mathrm{NH}_{4}\right) \mathrm{OH}$ followed by $1 \mathrm{~L}$ of $4 \%$ sodium sulfate solution. The $\mathrm{pH}$ of the prepared metal salt solution(s) $(\approx$ $100 \mathrm{~mL}$ ) was adjusted to the required value by addition of the buffer solution before starting the adsorption experiments. The $\mathrm{pH}-$ adjusted solution was then run through the resin in the column. Ion exchange experiments were conducted by packing $0.2 \mathrm{~g}$ Lewisite MP 600 in the column. A solution containing the metal ions was then poured onto the top of the column and allowed to flow at a rate of $0.5 \mathrm{~mL} / \mathrm{min}$. The solution was recycled through the column for completely satisfying adsorption of the metal ions.
The effluent was collected in a separating flask. The chloride content in the aliquots from each leach was determined by titration against standard $0.05 \mathrm{~N}$ silver nitrate using potassium chromate as an indicator. Stripping of the loaded metals was conducted by eluting with $4 \mathrm{M} \mathrm{HCl}$ solution. The collected chloride solutions were separately concentrated by evaporation under vacuum. Chloride was either electrolyzed to prepare the respective metal or converted to insoluble carbonate that was reacted with the acid of concern (inorganic or organic) to prepare the required salt.

Determination of chromium, zinc, cadmium and nickel ions was carried out with the help of a UV-visible atomic absorption spectrophotometer Milton Roy model 20D for the resin and the metals ions determination.

The $\mathrm{pH}$-adjusted solution was then run through the resin in the column. Ion exchange experiments were conducted by packing 0.2 g Lewisite MP 600 in the column. The solution containing the metal ions was then poured onto the top of the column and allowed to flow at a rate of $0.5 \mathrm{~mL} / \mathrm{min}$. The solution was recycled through the column for completely satisfying adsorption of the metal ions.

The effluent was collected in a separating flask. The chloride content in the aliquots from each leach was determined by titration against standard $0.05 \mathrm{~N}$ silver nitrate using potassium chromate as an indicator. Stripping of the loaded metals was conducted by eluting with $4 \mathrm{M} \mathrm{HCl}$ solution. The collected chloride solutions were separately concentrated by evaporation under vacuum. Chloride was either electrolyzed to prepare the respective metal or converted to insoluble carbonate that was reacted with the acid of concern (inorganic or organic) to prepare the required salt.

Determination of chromium, zinc, cadmium and nickel ions was carried out with the help of a UV-visible atomic absorption spectrophotometer Milton Roy model 20D for the resin and the metals ions determination.

The $\mathrm{pH}$ value was measured by a based bench $\mathrm{pH}$ meter (Hanna model 211) fitted with HFB electrode. Measurements were conducted at $25^{\circ} \mathrm{C} \pm 0.2^{\circ} \mathrm{C}$.

The exchange capacity of the resin $\varepsilon_{\mathrm{r}}$ was computed from the following relation, Kunin, [17].

$$
\mathrm{E}_{\mathrm{r}}=\frac{\mathrm{V}_{(\mathrm{AgnO})} . \mathrm{N}_{(\mathrm{AgNO} 3)}}{\mathrm{W}_{\mathrm{r}}} \times 100
$$

Where $\mathrm{V}$ is the volume, $\mathrm{N}$ is the normality, $\mathrm{W}$ is the weight of the resin sample.

The distribution coefficient $K_{d}$ was determined from the relation given by John et al. [18]

$$
\mathrm{K}_{\mathrm{D}=}=\frac{\Delta \mathrm{C} \times \mathrm{V}_{\text {metal solution }}}{\mathrm{C}_{\mathrm{f} \cdot \mathrm{g}} \mathrm{g}}
$$

Where $\Delta \mathrm{C}$ is the change in concentration of the metal in solution before $\left(\mathrm{C}_{\mathrm{i}}\right)$ and after the experiment $\left(\mathrm{C}_{\mathrm{f}}\right), \mathrm{V}$ is the volume and $\mathrm{g}$ are the weight of the resin. Sorption extent (\%) was determined from the relation reported by Fethiye and Erol 2005 [19].

$$
\text { Sorption } \%=\Delta \mathrm{C} / \mathrm{C}_{\mathrm{i}} \mathrm{X} 100
$$




\subsection{Method of preparation of the metals and their salts}

The exhausted batteries under investigation were dissolved in 1.1 stoichiometric ratios of $3 \mathrm{M}$ nitric acid at room temperature till complete dissolution (usually takes time). The volume of the solution as adjusted to $250 \mathrm{ml}$ by distilled water. The nitrate solution was treated with an ammonia solution. The prepared nitrate or hydroxide salts were used to prepare free metals of lead or base metals by reduction with ascorbic acid or to prepare carbonate, chloride, sulphate, format, oxalate, citrate and acetate salts...

\section{Results and Discussion}

Fig. 4 shows the XRD of the lead paste. It is seen that the major content is lead sulphate, lead oxide while lead dioxide is minor. It is seen that major peaks appeared with intensity $>600$ at $2 \theta 20-35$ are assigned to the presence of lead sulphate, lead oxide $\mathrm{PbO}$ and lead dioxide $\mathrm{PbO}_{2}$. These compounds were also detected with lower intensity $(<200)$ at $2 \theta ? 50-<80$. Fig 5 shows the XRD pattern examined at low $2 \theta$ value of 18 and more. Fig. 5 confirms the presence of minor elements of nickel and cobalt. Table 3 confirms the presence of these minor elements. It is worth noting that lead alloy with this composition is recommended in the manufacture of batteries to help adequate mechanical and thermal stability of the battery during recharging and discharging operations.

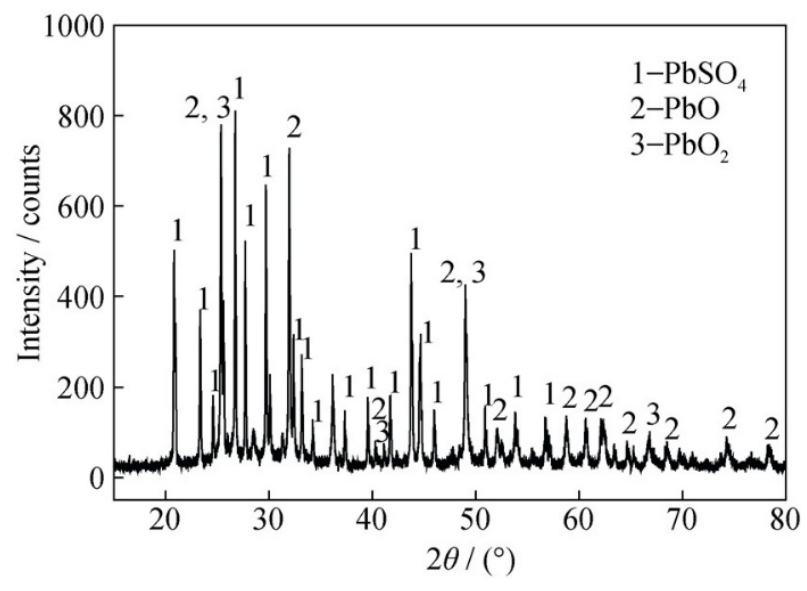

Figure 4 The XRD of the lead paste 46

It is seen that lead metal conistitutes the major element that amounjts to $94.2 \%$ by weight. Other elements are in minor percentages. It is also seen that the weight percentage of these minor elements decreases in the order $\mathrm{Si}, \mathrm{Al}, \mathrm{Ru}, \mathrm{Zr}, \mathrm{Co} \mathrm{Ni}, \mathrm{Cu}$ and $\mathrm{Zn}$. The common elements in commercial use aovered by solvent extraction technique.

This is very clear that lead compounds in grey plates were lead sulphate. The lead compounds in the brown plates were lead oxide and partly lead dioxide. Lead compounds decreased in the order sulphate, oxide and dioxide. Concerning the minor compounds, $\mathrm{Ni}$ and cobalt were present nearly in equal amounts (Fig. 3). Table 3 shows the elements present in the exhausted plates as detected by XRF analysis.

It is seen that lead metal is the major element that constitutes $94.2 \%$ by weight. Other elements are in minor percentages. It is also seen that the weight percentage of these minor elements decreases in the order $\mathrm{Si}, \mathrm{Al}, \mathrm{Ru}, \mathrm{Zr}, \mathrm{Co}-\mathrm{Ni}$, $\mathrm{Cu}$ and $\mathrm{Zn}$. The common elements in commercial use are $\mathrm{Ni}$ and $\mathrm{Co}$ and $\mathrm{Zn}$. These were recovered by solvent extraction.

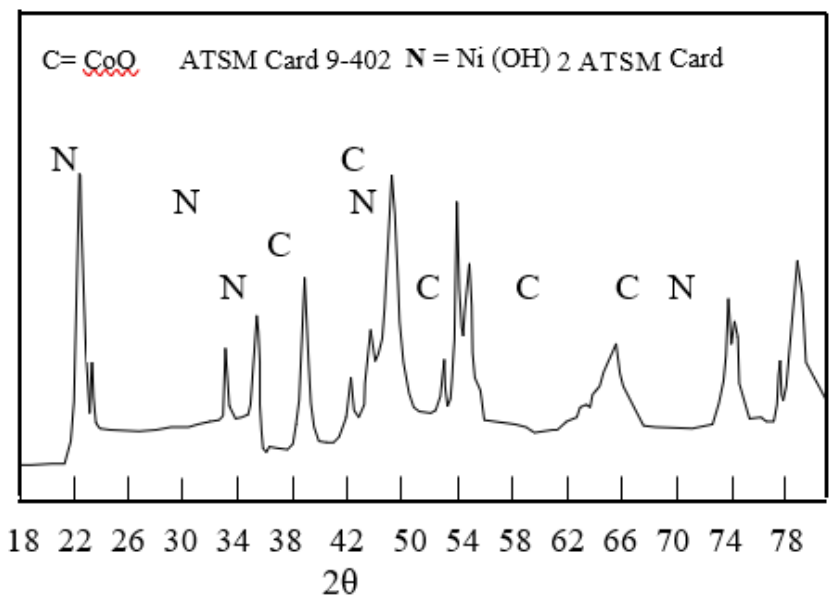

Figure $5 \mathrm{XRD}$ pattern of the minor elements in the battery positive plates

Table 3 The XRF analysis of the elements present in the exhausted plate

\begin{tabular}{|l|l|}
\hline Metal & \% wt. \\
\hline Lead & 94.2 \\
Nickel & 0.05 \\
zinc & 0.0030 \\
Cobalt & 0.053 \\
Copper & 0.0272 \\
Zirconium & 0.0727 \\
Rhobidium & 0.0842 \\
Aluminium & 0.12 \\
Silicon & 0.24 \\
\hline
\end{tabular}

technique. Fig. 6 shows the extent of leaching lead from the spent plates using $2 \mathrm{M}$ and $5 \mathrm{M}$ nitric acid at room temperature. The use of sulphuric acid instead of nitric acid was discarded because the reaction stopped rapidly because lead sulphate is immiscible in water. It can be seen that the leaching process takes time to react with lead compounds. The extent of leaching increases with time to give the maximum extent of $38.4 \%$ after 7 days with $2 \mathrm{~N}$ acid. More concentrated nitric acid (5M) gives less extent of leaching (32\%). using $2 \mathrm{M}$ and $5 \mathrm{M}$ nitric acid at $80{ }^{\circ} \mathrm{C}$ shows that $5 \mathrm{M}$ nitric is more reactive as compared to $2 \mathrm{M}$ concentration. After 6 days the maximum extent of leaching amounts to $38 \$$ and $14 \$$ with $5 \mathrm{M}$ and $2 \mathrm{M}$ respectively

Figure 7 shows the effect of time on the leaching extent of the brown paste of the battery using $3 \mathrm{M}$ and $5 \mathrm{M}$ nitric acid at $80 \mathrm{C}$. It can be seen that the extent of leaching increases linearly with increase in time attaining a value of about $40 \%$ after 6 days. The corresponding value taking place with $3 \mathrm{M}$ acid amounts to about $10 \%$. Figure 8 shows the effect of nitric acid concentration on 
leaching lead sulphate and lead oxide at room temperature for 6 days. It is seen that lead sulphate displays a higher extent of leaching compared to lead oxide up to 5 days. After 6 days lead oxide is readily more leached as compared to lead sulphate.

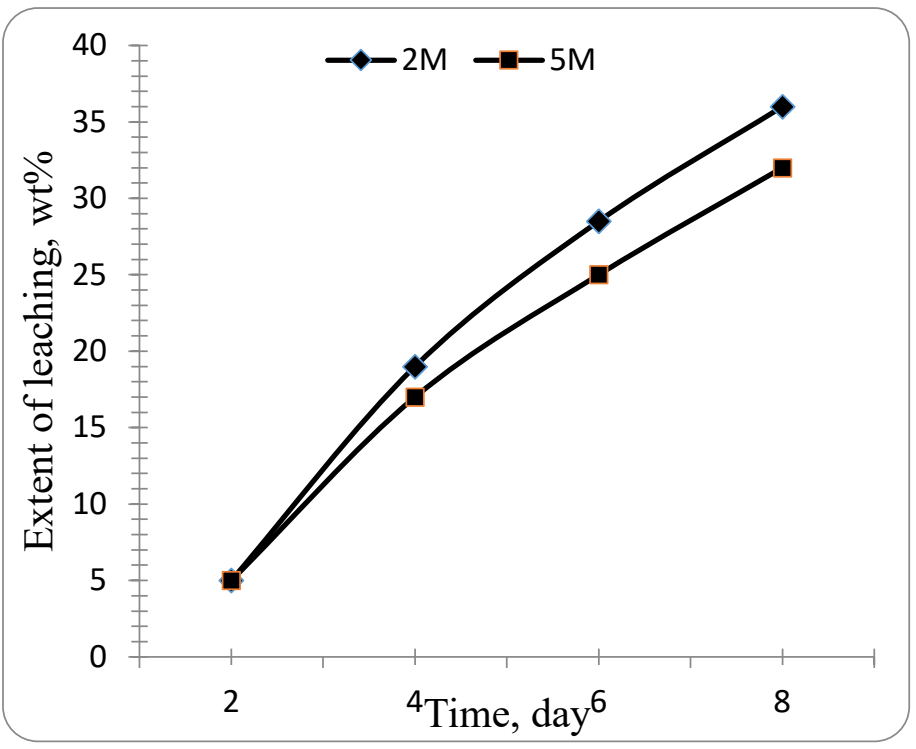

Figure. 6 Effect of time on the leaching extent of grey grids using $2 \mathrm{M}$ and $5 \mathrm{M}$ nitric acid at room temperature

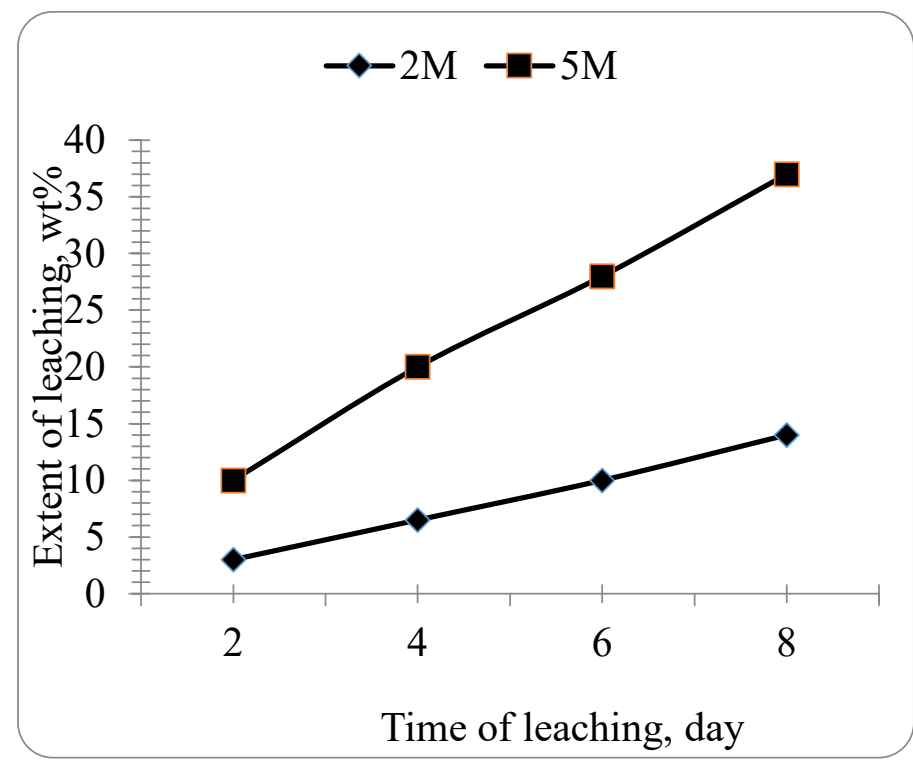

Figure 7. The effect of time on the extent of acid leaching of brown paste using $2 \mathrm{M}$ and $5 \mathrm{M}$ nitric acid at $80^{\circ} \mathrm{C}$

Fig. 9 shows the effect of temperature on the leaching extent of lead oxide present in the battery. It can be seen that increasing the leaching temperature increases the leaching extent. The optimum acid concentration is $3.5 \mathrm{M}$.

Fig. 10 shows the coefficient of distribution $\mathrm{Kd}$ value of $\mathrm{Zn}$ ions extracted from the leaching solution using the exchange resin Lewatite. with different concentration of $\mathrm{Zn}$ as affected by the amount of the ion exchange resin added at room temperature. It can be seen that the coefficient extent decreases regularly with the corresponding increase in the amount of the used resin and the concentration of $\mathrm{Zn}$ ions in the solution.

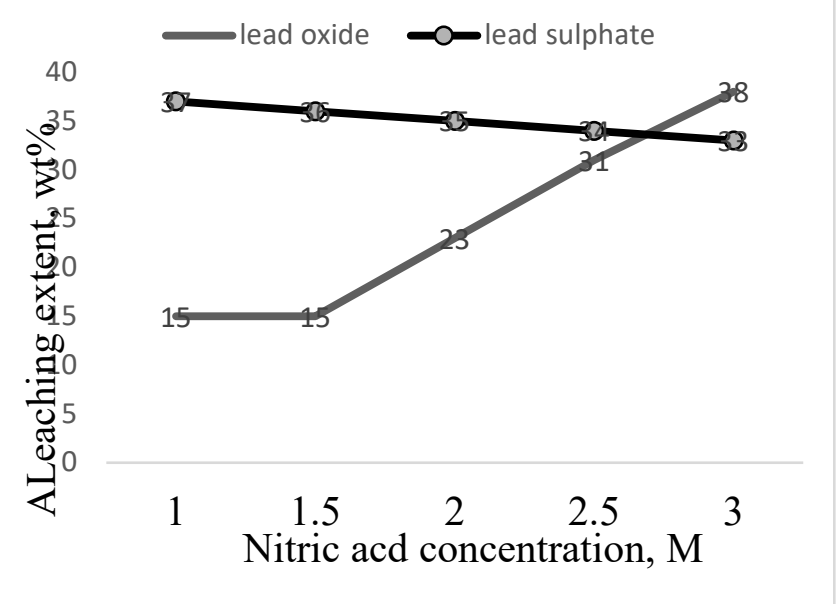

Figure 8 Effect of nitric acid concentration on leaching lead sulphate and lead oxide at room temperature for 6 days.

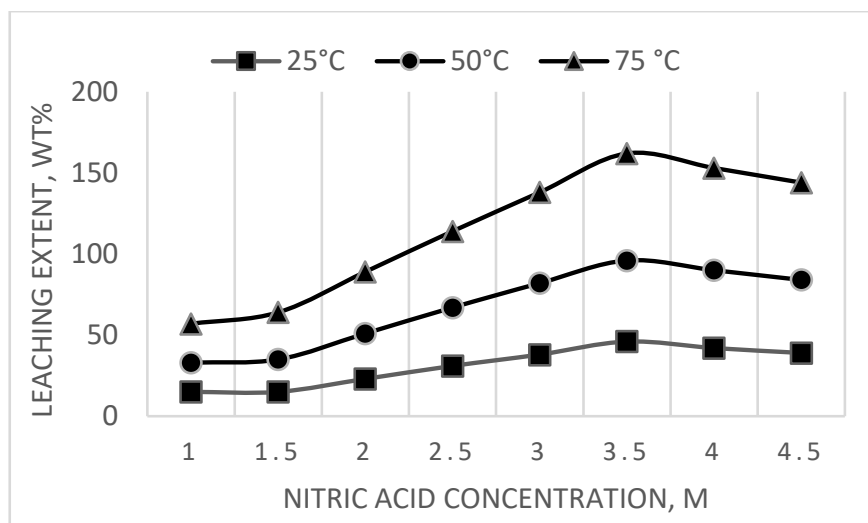

Figure 9 Effect of temperature on the leaching extent of lead oxide present in the battery.

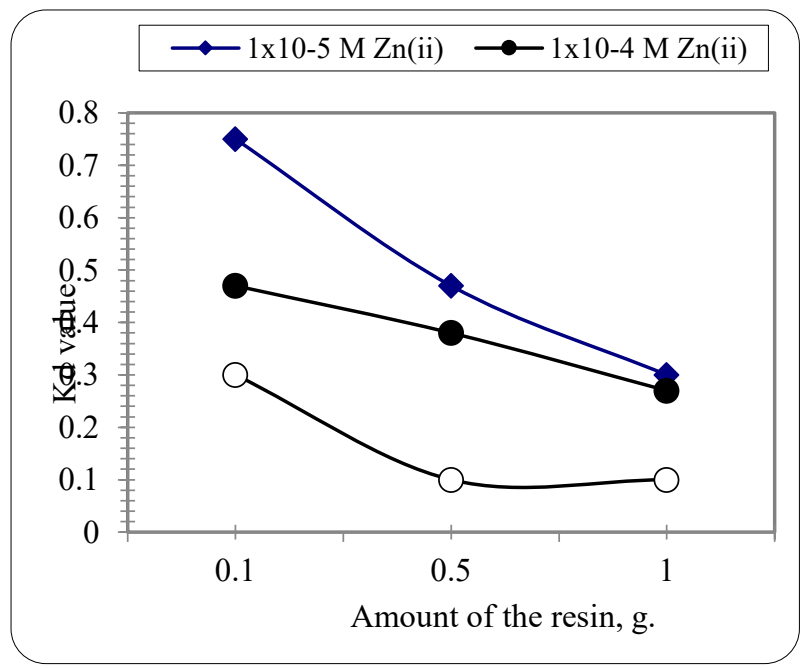

Figure 10 The $\mathrm{Kd}$ value for $\mathrm{Zn}$ from solution with different concentration of $\mathrm{Zn}$ as affected by the amount of the ion exchange resin

Fig. 11 shows The Kd value for Co from solution with different concentration of $\mathrm{Co}$ as affected by the amount of the ion exchange resin. It can be seen that with and the same metal ion concentration in the solution, the $\mathrm{Kd}$ value increases with the decrease in 
concentration. This statement is logic as given in equation (2). The value of the denominator decreases that gives a corresponding increase in $\mathrm{Kd}$ value. The effect of change in $\mathrm{g}$ value is less significant as compared to the change in $\mathrm{C}$ value.

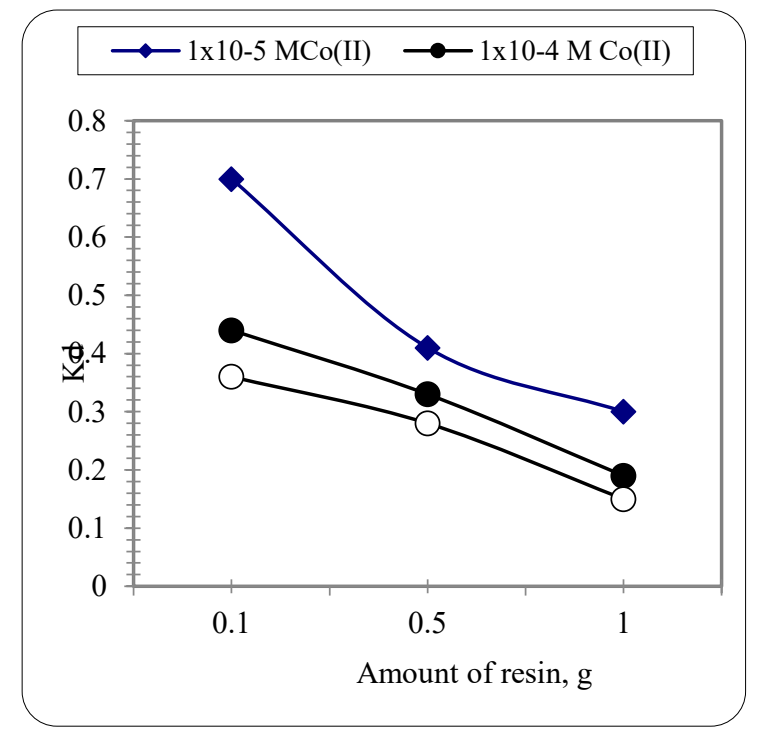

Figure 11 The Kd value for Co extraction from solution with different concentration of $\mathrm{Co}$ as affected by the amount of the ion exchange resin

Figure 12 shows the effect of $\mathrm{pH}$ value on the Kd value with nickel ions. It can be seen that the effect of $\mathrm{pH}$ becomes significant at values $\geq 8.5$. At $\mathrm{pH} 9$ the $\mathrm{Kd}$ value is highest. Fig. 12 confirms the same findings obtained with $\mathrm{Zn}$ ions given in Fig. 13.

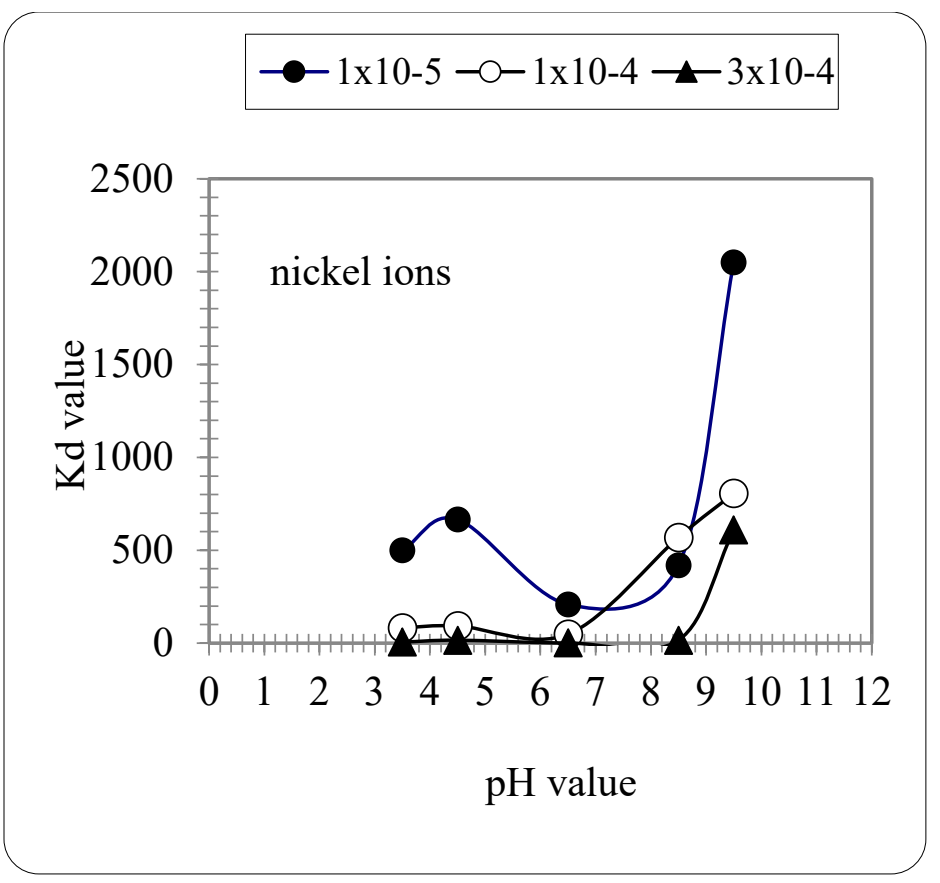

Figure 12 The Kd value for Ni extraction from solution with different concentration as affected by the $\mathrm{pH}$ value of the extraction medium

Fig. 14 shows the effect of type of solvent on the obtained metal powder after stripping. It iss seen that solvent 2 gives $\mathrm{Ni}$ and $\mathrm{Al}$ in nanosize. Solvent 1 gives the same effect with Aluminium. Other solvents give metals with larger size.

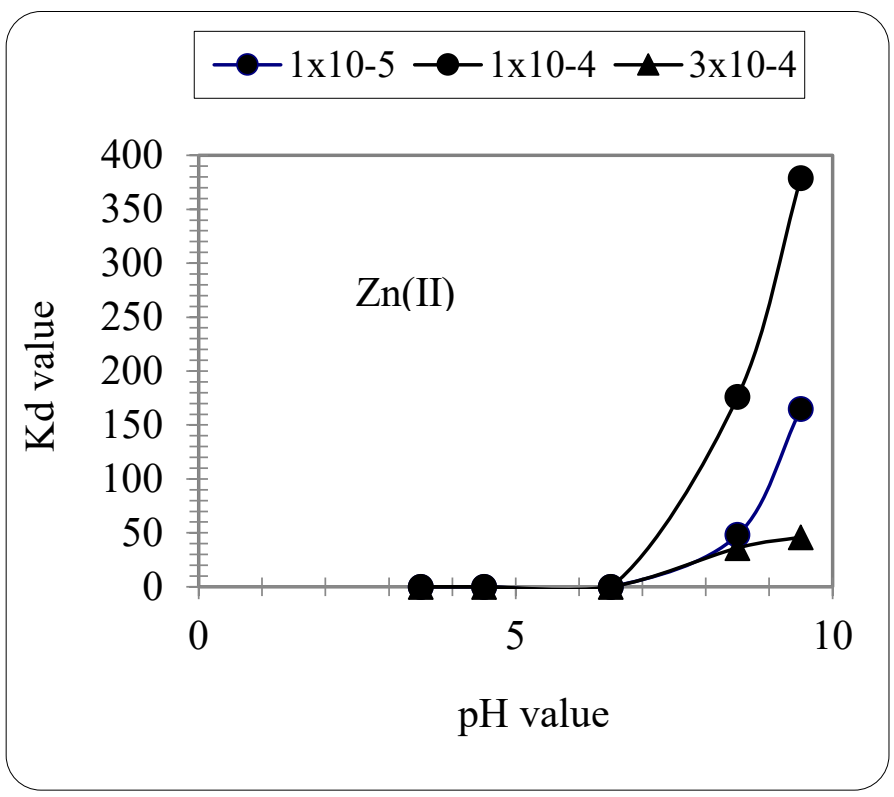

Figure. 13 Effect of $\mathrm{pH}$ value on the $\mathrm{Kd}$ value with $\mathrm{Zn}$ ions.

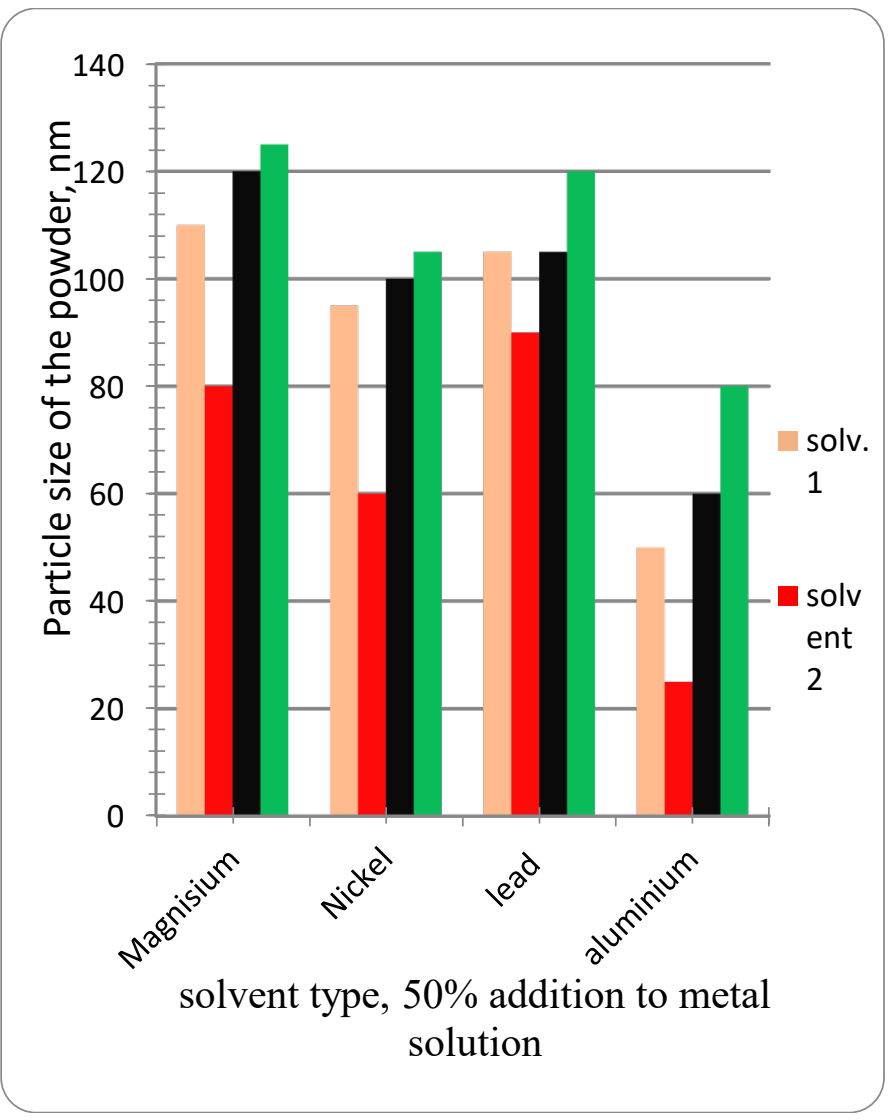

Figure. 14 The effect of type of solvent on the obtained metal powder after stripping

Table 3 shows that lead content in the battery amounts to 94.2 $\%$ by weight together with other 8 elements in a minor percentage. Leaching process in this study was carried out at room temperature to save energy although it takes time. The chemical reactions to leach the detected metals taking place according to

$$
\mathrm{M}+\mathrm{xHNO}_{3} \longrightarrow \mathrm{M}\left(\mathrm{NO}_{3}\right) \mathrm{x}_{-1} \mathrm{NO}_{2}+\mathrm{H}_{2} \mathrm{O} \ldots \ldots
$$


M.A. Rabah et al. / Advances in Science, Technology and Engineering Systems Journal Vol. 4, No. 4, 529-538 (2019)

Table 4 shows the prepared salts from the spent battery and its purity extent. Table 5 shows the chemical composition of the residue

Table 4 the prepared salts of lead and its purity extent

\begin{tabular}{llll}
\hline $\begin{array}{l}\text { Lead } \\
\text { salt }\end{array}$ & $\begin{array}{l}\text { Added } \\
\text { reagent }\end{array}$ & $\begin{array}{l}\text { Prepared } \\
\text { salt }\end{array}$ & $\begin{array}{l}\text { Purity of } \\
\text { product }\end{array}$ \\
\hline $\begin{array}{l}\text { Lead } \\
\text { nitrate }\end{array}$ & $\begin{array}{l}\text { Sulphric } \\
\text { acid }\end{array}$ & $\begin{array}{l}\text { Lead } \\
\text { sulphate }\end{array}$ & 99.6 \\
& HCl & $\begin{array}{l}\text { Lead } \\
\text { chloride }\end{array}$ & 99.2 \\
& & &
\end{tabular}

\begin{tabular}{llll} 
& $\begin{array}{l}\text { Sod. } \\
\text { carbonate }\end{array}$ & $\begin{array}{l}\text { L:ead } \\
\text { carbonate }\end{array}$ & 100 \\
lead & Acetic & Lead & pure \\
hydroxide & acid & acetate & \\
& $\begin{array}{l}\text { Oxalic } \\
\text { acid }\end{array}$ & $\begin{array}{l}\text { Lead } \\
\text { oxalate }\end{array}$ & pure \\
& Formic & Lead & pure \\
acid & format & \\
Citric & Lead & pure \\
acid & citrate & \\
\hline
\end{tabular}

The unleached fraction remaining after nitric acid leaching was analyzed by XRF.

According to the law of mass action, increasing the nitric acid concentration in the reactants would enhance the leaching extent of lead oxide whereas lead sulphate was unleached. This finding finds support from the fact that sulphate radical is strong to be leached with nitric acid at room temperature. The leaching process is judged by the results given in Fig. 8. The nitrate salt was converted to hydroxide with the action of ammonia solution. This step was necessary to reduce the hydroxide gel to elemental nanoparticles of lead by ascorbic acid as follows:

Reduction of metals hydroxides

Ascorbic acid reduces hydroxide salts of lead and basic metals to free fine particles as follows

$\mathrm{Pb}(\mathrm{OH})_{2}+2$ ascorbic acid $\longrightarrow 2 \mathrm{H}_{2} \mathrm{O}+\mathrm{Pb}+2$ oxidized ascorbic acid.

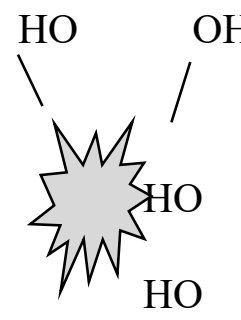

$\mathrm{O}$

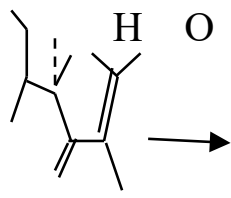

$\mathrm{OH}$

$\mathrm{HO}$

\section{$\mathrm{OH}$}

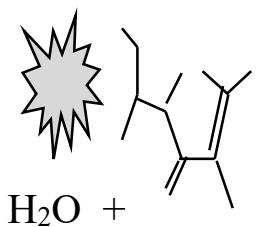

$\mathrm{H}_{2} \mathrm{O}+$
Table 5 the chemical composition of the residue

\begin{tabular}{ll}
\hline Plate & Composition \\
\hline Grey & Lead sulphate $100 \%$ \\
Brown & Lead oxide $\mathrm{PbO} / \mathrm{PbO}_{2}$ \\
\hline
\end{tabular}

Lead metal in battery plates is present in three forms; a grid made of lead alloy in the form of net-shaped structure loaded with lead sulphate or lead oxide-free metal. Heating the terminal tap of the battery gives lead alloy composed of lead-aluminiummagnesium as revealed from EDX pattern confirmed with SEM image given in Fig. 14. It is composed of $95.83 \%$ wt $\mathrm{Pb} 1.25 \%$ $\mathrm{Mg}$ and $2.92 \% \mathrm{Al}$. SEM/EDX is a combination tool, with two instruments working in partnership [20]. These two instruments operate simultaneously to complement each other's data acquisition, guided by the instrumental operator. Scanning electron microscopy (SEM) provides an image (i.e., morphological information or surface features) on a magnified scale $-X 10$ to $X$ 100,000 , although the usual range is perhaps X50 to X5000. Energy dispersive $\mathrm{x}$-ray (EDX) determines the elemental composition of an area, with a sensitivity of perhaps 0.1 to 1 per cent composition and with a spatial resolution of $1 \mu \mathrm{m}$. EDX is commonly used for elements with atomic number $\geq 11$ (sodium), but thin window EDX systems can also detect elements with atomic number $\geq 5$ (boron). With these two instruments operating together, the instrumentalist can scan areas of potential interest, zoom in with higher magnification, and determine elemental compositions in selected areas of interest.

Lead is a soft and ductile metal and lead alloys are used on a large scale. The alloying elements may be antimony, tin, arsenic, and calcium are. Antimony is used to give greater hardness and strength, as in storage battery grids ( 0.5 to $25 \%)$, sheet, pipe, and castings. Antimony contents in the lead-antimony alloys are usually 2 to $5 \%$.
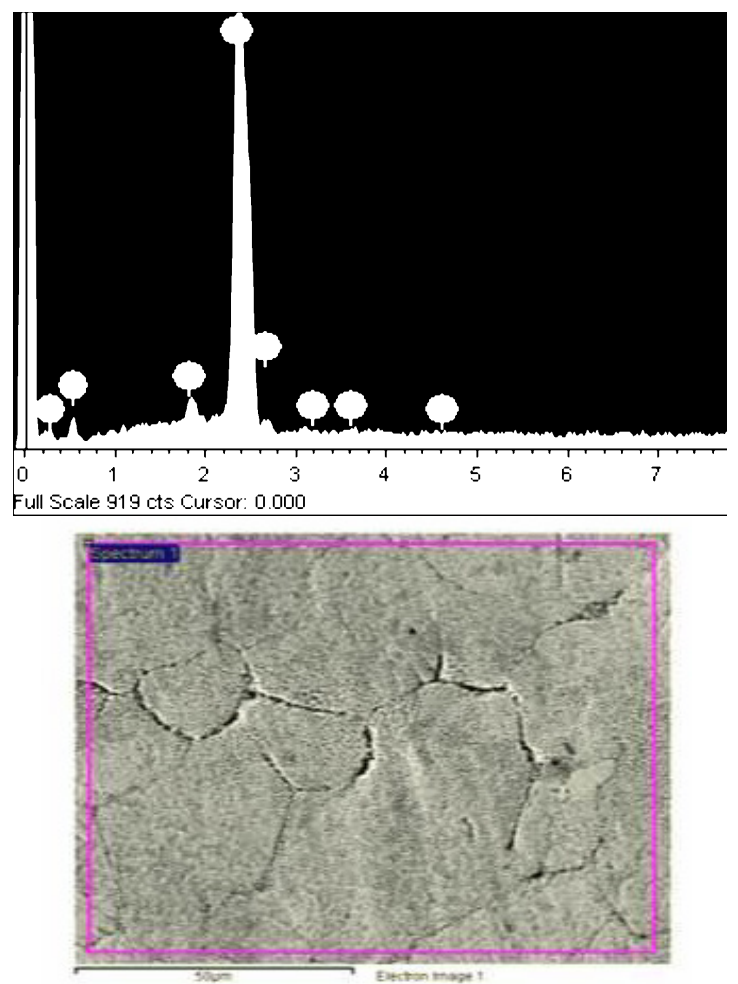

Figure 15 (a) The EDX of the melted terminal tap, (b) the SEM of $\mathrm{Pb} \mathrm{Al}$ alloy

Lead hydroxide $\quad+2$ ascorbic acid water lead metal oxidized ascorbic acid 


\section{M.A. Rabah et al. / Advances in Science, Technology and Engineering Systems Journal Vol. 4, No. 4, 529-538 (2019)}

Fig. 15 shows the EDX and SEM images of lead obtained by melting the terminal tap of the battery under an inert atmosphere. Fig $15\{a\}$ is the EDX pattern of a lead alloy of the terminal tap. Fig. 15(b) is the SEM of the $\mathrm{Pb} \mathrm{Al}$. Alloy after annealing at $500^{\circ} \mathrm{C}$ Results revealed that only $15-20 \%$ of lead is obtained by simple heating of all the battery plates even in reducing conditions. It becomes legitimate to apply the modified method capable to produce the high extent of lead recovery. In this context, Yoheeswaran 1 et al., [15], reported that the recovery of $95 \%$ of lead metal from lead-acid batteries by $2 \mathrm{M}$ of nitric acid It is found that $95 \%$ of lead metal was leached and more than $90 \%$ of lead metal can be recovered by electrochemical method with low current efficiency from Pan the leaching solution.

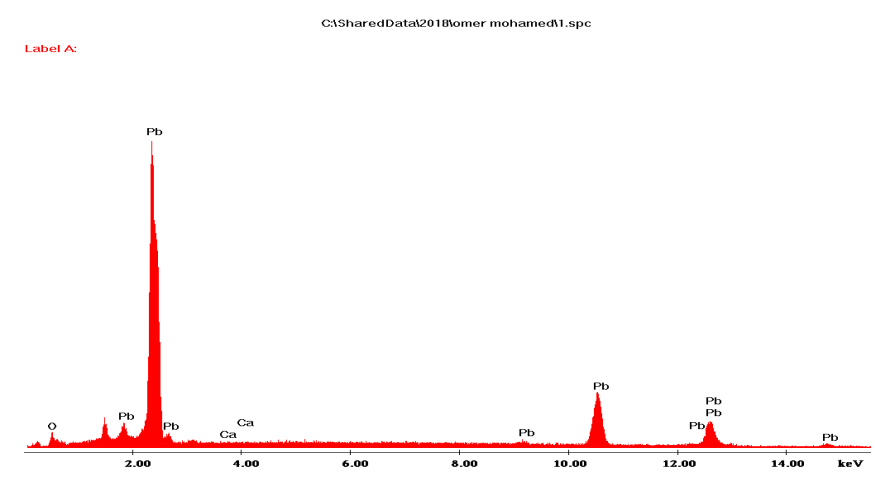

EDX pattern of lead $\mathrm{Ca}, 0.18 \%, 3 \% \mathrm{Al}, 94 \% \mathrm{~Pb}$

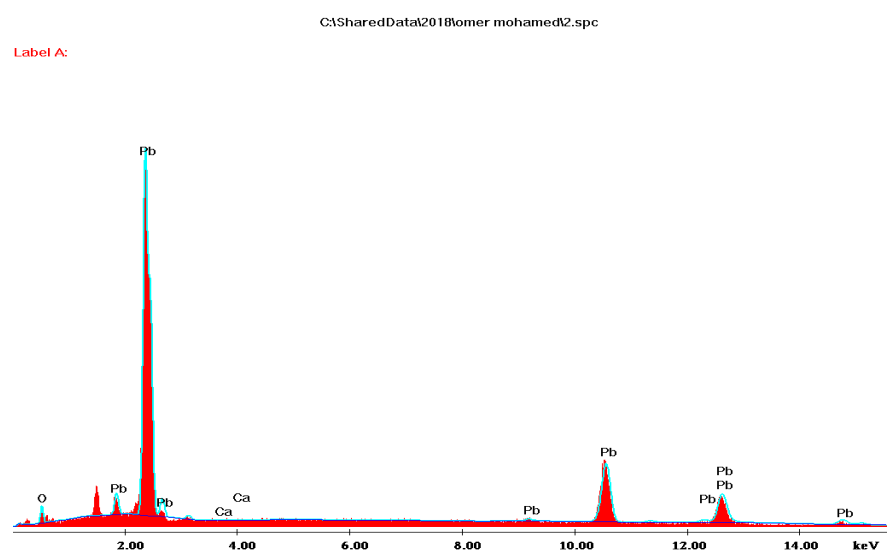

EDX pattern of lead $\mathrm{Ca} 0.08 \%$

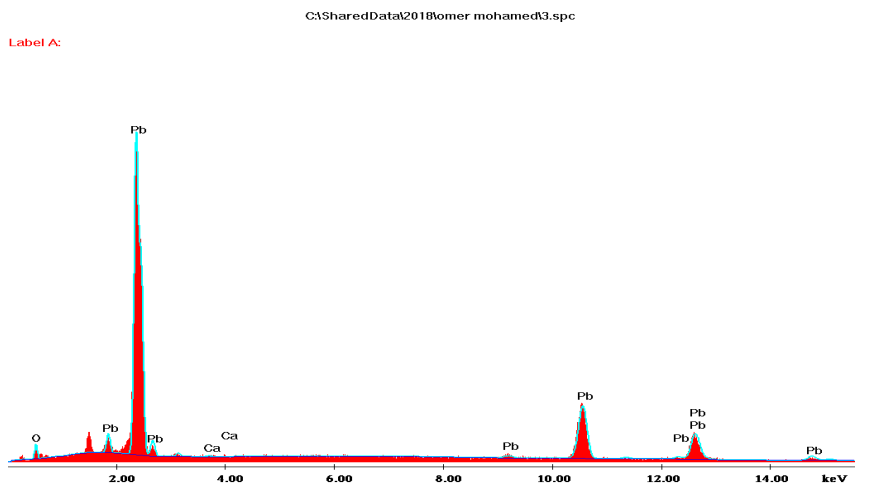

$\mathrm{Pb} 93.66 \% \mathrm{Ca} 0.32 \%$, Ca $0.32 \%$,

Figure. $16 \mathrm{EDX}$ pattern of lead alloys containing different alloying elements.
The method adopted seemed promising and had great potential for removal of lead from used lead-acid batteries. Fig. 16 shows the EDX pattern of lead alloys with calcium $(0.018 \%$ and aluminium $0.03 \%$, lead alloyed with $0.08 \%$ calcium and $0.32 \%$ calcium. In this pattern, the main electron beam appeared at 3.00 $\mathrm{Kev}$ is stable at a relative height of $66.2 \%$ with all alloys is assigned to elemental lead. The spectra of the alloying elements appeared at $11 \mathrm{Kev}$ with lower relative height pf $10 \%$ and $7 \%$ are for $\mathrm{Al}$ and Calcium respectively [22].

Unified Numbering System (UNS) designations for various pure lead grades and lead-base alloys is as follows [23].

- $\quad$ Pure leads L5xx00 - L5xx99

- Lead - calcium alloys L5x700 - L5x899

- $\quad$ Lead - strontium alloys L552xx - L55299

Lead-calcium alloys are used in several applications, particularly, storage battery grids and casting applications. $\mathrm{Pb}-\mathrm{Ca}$ alloys contain 0.03 to $0.15 \% \mathrm{Ca}$. aluminum is now added to calcium-lead and calcium-tin-lead alloys to stabilize calcium. Alloying tin to lead increases hardness and strength. However, lead-tin alloys are usually used for their good melting, casting, and physical properties as in type metals and solders.

\section{Conclusion}

The output conclusion of this work is that exhausted rechargeable batteries are essential resource for recovery of nonferrous precious metals like lead and lead alloys. Other metals value $(\mathrm{Ca} . \mathrm{Al}, \mathrm{Ni}, \mathrm{Co})$ are present and were successfully recovered. The method used to achieve the goal of this study was simple and friendly environmentally. Preparation of lead metal was matched by a combined hydrometallurgy and pyrometallurgy. The battery was dismantled and the plates were separately leached in nitric acid whereby the nitrate salt was converted to hydroxide by ammonia solution. The hydroxide was reduced to metal lead nanoparticles by ascorbic acid, Alternatively, the lead sulphate and oxide packing the grids were thermally heated with carbon at about 900 ${ }^{\circ} \mathrm{C}$ to give free metal lead. Alloys of lead with calcium and aluminium has been matched applying the combined hydrometallurgy and pyro metallurgy methods. The extent of recovery amounts to $94.3 \%$ with pure lead and $99.6 \%$ with lead alloys of aluminium and calcium. Valuable salts of lead including organic salts were also prepared in highly pure grade.

\section{References}

[1] E. R, Cole A. Y. Lee. D.L. Paulson,"Recovery of Lead from Battery Sludge by Electrowinning", JOM, August 1983, Volume 35, Issue 8, pp $42-46,1983$

[2] A., Smaniotto, A. Antunes, I. doNascimento, L. Filho D. Luciana, D Venquiaruto. D. Oliveira, M., AltemirMossi H. Treichel and R. Dallago J. hazmat..07. pp 26. 2009.

[3] C. S Chen, Y.J $J^{2}$ Shih, Y.H. Huang "Recovery of lead from smelting fly ash of waste lead-acid battery by leaching and electrowinning. $m$ Waste Management, 52:212-20, 2016

[4] Junqing Pan' ChaoZhang Yanzhi Sun Zihao Wang "A new process of lead recovery from waste lead-acid batteries by electrolysis of alkaline lead oxide solution", Electrochemistry Communications. V 19, June 2012, pp 70-72, 2012.

[5] X., Chen, "Hydrometallurgical process for the recovery of metal values from spent lithium-ion batteries in citric acid media", Waste management and research J. Vol 32, Issue 11, 2014. https://doi.org/10.1177/0734242X14557380 
[6] D. Andrews, A, Raychaudhuri, and C. Frias. Environmentally sound technologies for recycling secondary lead, J. Power Source, 88. V1, p. 124., 2000.

[7] X. Chen, , Hydrometallurgical process for the recovery of metal values from spent lithium-ion batteries in citric acid media, WASTE MANAGEMENT AND RESEARCH J. Vol 32, Issue 11, 2014

[8] E. Margulis, (Hafia, IL), Process for the recovery of lead from spent batteries, USA Patent 4058396, 10/27/ 1998

[9] G.Z. Chen, D.J. Fray, and T.W. Farthing, Direct electrochemical reduction of titanium dioxide to titanium in molten calcium chloride, Nature, 407(6). 2000

[10] D. Zhou, C.Y. Zhao, and Y. Tian, Review on thermal energy storage with phase change materials (PCMs) in building applications, Appl. Energy, 92 p. 593.2012

[11] Y.Y. Long, J.Z. Li, D.H. Timmer, R.E. Jones, and M.A. Gonzalez, Modeling and optimization of the molten salt cleaning process, J. Clean. Prod., 68, p. 243. 2013

[12] J.G. Yang, C.B. Tang, Y.M. Chen, and M.T. Tang, Separation of antimony from a stibnite concentrate through a low-temperature smelting process to eliminate SO emission, Metall. Mater. Trans. B, 42 No. 1, p. 30.2011

[13] N. Badawy, M. A. Rabah and R. Hasan 2013 Recovery of some heavy metals from electroplating rinsing wastewater by LEWATIT MP 600 ion exchange resin., Int. Journal of Environment and waste management, IJEWM, 12(1) 33-51. DOI: 10.1504/IJEWM. 054778. 2013

[14] Y.J.-Chu, and G. T. Townsend, "Leaching of Lead from Computer Printed Wire Boards and Cathode Ray Tubes by Municipal Solid Waste Landfill Leachates Department of Environmental Engineering Sciences, University of Florida, Gainesville, Florida 32611-6450 Environ. Sci. Technol., 2003, 37 (20), pp 4778-478 2003

[15] E. Yoheeswaran1, S. Govindaradjane, and T. Sundararajan, "Recovery of Lead Metal from Lead Acid Battery by Hydrometallurgical Method", International Journal of Engineering Science and Innovative Technology (IJESIT) Volume 2, Issue 1, January 2013

[16] Viraja Bhat et., al, "Development of an integrated model to recover precious metals from electronic scrap - A novel strategy for e-waste management, Procedia social and behavioral 37, 397-406, 2012.

[17] Y. Ma and K, Qui "Recovery of lead from lead paste in spent lead acid battery by hydrometallurgical desulfurization and vacuum thermal reduction", Waste Management 40. 03, 010,2 015

[18] R. Kunin, A., Rohn. and H. Company (Eds), Philadelphia Pennsylvania, New York, John Wiley and Sons, Second Edition, 1170.2016

[19] E,G, John, W., Gary and A., Georgiann Preconcentration of trace metal ions by combined complexation-anion exchange Part I. Cobalt, zinc and cadmium with 2-(3'-sulfobenzoyl)-pyridine-2-pyridylhydrazone. Anal. Chim. Acta, 81, 349. 1976.

[20] G. Fethiye and P. Erol Removal of Cr (VI) from aqueous solution by two Lewatit-anion exchange resins. Journal of Hazardous Materials. 119, (1-3), 175-182. 2005.

[21] E.R., Bagherian, F. Ongchang, M., Cooper, et al., "Effect of antimony addition relative to microstructure and mechanical properties of continuous cast lead alloy", Metal, May 25th - 27th 2016, Brno, Czech Republic. 2016.

[22] M. T. Riaz, Y. Fan, J. Ahmad, M. A. Khan, and E. M. Ahmed, "Research on the Protection of Hybrid HVDC System," in 2018 International Conference on Power Generation Systems and Renewable Energy Technologies (PGSRET), 2018, pp. 1-6.

[23] https://en.wikipedia.org/wiki/Unified numbering system. 